\title{
Effect of Fusarium graminearum and Infection Index on Germination and Vigor of Maize Seeds
}

\author{
Juliana A. Galli ${ }^{1}$, Simone A. Fessel ${ }^{2} \&$ Rita C. Panizzi ${ }^{3}$ \\ ${ }^{1}$ Aluna de Doutorado do Curso de Produção Vegetal, FCAV/UNESP, Via de Acesso Prof. Paulo D. Castellane, $\mathrm{s} / \mathrm{n}^{\circ}$, \\ CEP 14884-900, Jaboticabal, SP, e-mail: julianagalli@zipmail.com.br; ${ }^{2}$ Aluna de Doutorado do Curso de Produção \\ e Tecnologia de Sementes, FCAV/UNESP; ${ }^{3}$ Profa. Departamento de Fitossanidade, FCAV/UNESP
}

(Accepted for publication on 07/07/2005)

Corresponding author: Juliana Altafin Galli

GALLI, J.A., FESSEL, S.A. \& PANIZZI, R.C. Effect of Fusarium graminearum and infection index on germination and vigor of maize seeds. Fitopatologia Brasileira 30:470-474. 2005.

\begin{abstract}
Pathogens in maize (Zea mays) seeds cause serious problems, such as the loss of their capacity to germinative. The objectives of this study were to identify the optimal period for infection of maize seeds on agar colonized by Fusarium graminearum, when incubated for 4, 8, 16 and $32 \mathrm{~h}$, and to evaluate the effect of the fungus on the germination and vigor of seeds with different infection levels. After the respective incubation periods, the seeds were removed from the culture medium and submitted to the blotter test for $3 \mathrm{~min}$ with and without superficial disinfection with $1 \%$ solution of sodium hypochlorite. Once the optimal period for seed incubation was identified, seeds from the same sample were again placed on the colonized agar for infection. Germination and vigor tests (accelerated aging and cold test) were performed with a mixture of healthy seeds (placed on PDA medium) and inoculated seeds, resulting in seeds with 0, 20, 40, 60, 80 and $100 \%$ rates of infection. The results showed that a period of $32 \mathrm{~h}$ was long enough to obtain seeds infected by the pathogen. There were no significant effects of fungal infection on seed germination at any of the infection levels, probably due to the high vigor of the maize seed lot tested. Regarding vigor tests, infection levels differed significantly from the control ( $0 \%$ infection), but there were no significant differences among the infection levels.
\end{abstract}

Additional keywords: Zea mays, seed pathology.

\section{RESUMO}

Efeito de Fusarium graminearum e índice de infecção na germinação e vigor de sementes de milho

Patógenos em sementes de milho (Zea mays) causam sérios problemas, como a perda de sua capacidade germinativa. O objetivo do trabalho foi determinar qual o melhor tempo para infecção das sementes de milho com Fusarium graminearum, para posterior avaliação dos danos causados pelo fungo na germinação e vigor das mesmas. As sementes foram colocadas sobre meio de BDA contendo o patógeno e incubadas por 4, 8, 16 e $32 \mathrm{~h}$. Após os respectivos períodos de incubação, estas foram submetidas ao teste de sanidade (papel de filtro), com duas variações, sem e com assepsia superficial, usando hipoclorito de sódio a 1\% de cloro ativo, por $3 \mathrm{~min}$. Determinado o melhor tempo para infecção, outras sementes foram infetadas com o patógeno, para realização dos testes de germinação e vigor (envelhecimento acelerado e teste de frio) com uma mistura de sementes sadias (colocadas sobre o meio BDA) e sementes inoculadas, resultando em 0, 20, 40, 60, 80 e 100\% de sementes infetadas com o fungo em estudo. Os resultados obtidos mostraram que o período de incubação de $32 \mathrm{~h}$ foi suficiente para se obter sementes infetadas. Com relação à germinação, não houve diferenças significativas entre os diferentes níveis de infecção, provavelmente devido ao alto vigor das sementes de milho testadas. Quanto aos testes de vigor, os níveis de infecção diferiram significativamente da testemunha, apesar de não terem diferido entre si.

Palavras-chave adicionais: Zea mays, patologia de sementes.

\section{INTRODUCTION}

Fusarium graminearum (Schwabe) [teleomorph $=$ Gibberella zeae (Schwabe) Petch] causes stalk and ear rot of maize (Zea mays L.). Host debris is considered to be the principal reservoir of inoculum (Sutton, 1982), which includes ascospores, macroconidia and hyphal fragments surviving on host debris at or near the soil surface (Sutton,
1982; Khonga \& Sutton, 1988).

Fusarium spp. are associated with seeds of many members of the Poaceae, including maize, rice (Oryza sativa L.) and wheat (Triticum aestivum L.). Colonies usually consist of fluffy white to pink or coral-colored mycelium, often reaching $25 \mathrm{~mm}$ in diameter after one week of incubation. Spores are hyaline, canoe - or banana - shaped with pointed or rounded tips, usually subdivided into several 
cells with thin walls (septa), sometimes in spindle-shaped (elliptical) translucent to orange clusters, up to $0.5 \mathrm{~mm}$ in diameter (Copeland \& McDonald, 2001).

The characteristics of $F$. graminearum infection were described by Dickson (1923) and Pearson (1931), who stressed the restriction of symptoms to the mesocotyl-root area (subcrown internode and roots). Other symptoms of $F$. graminearum seedling blight are yellowing, wilting, chlorosis and stunting of seedlings due to a weakened root system (Dickson, 1923), and leaf chlorosis (Mohamed et al., 1968).

McGee (1988) listed Gibberella ear rot and stalk rot amongst maize diseases spread by seed-borne inoculum, but the transmission of the pathogen from maize seed to seedlings has not been clearly demonstrated.

Kabeere et al. (1997) reported that $F$. graminearum was shown to be transmitted from maize seeds to seedlings by consistent isolation from seedlings raised under aseptic conditions from seeds that carried the pathogen. Transmission rates were similar to seed-borne inoculum levels, suggesting that under favorable environmental conditions, the pathogen may be transferred from a high percentage of seeds to seedling.

The relative importance of seed-borne Fusarium spp. in maize has been studied over many years by various researchers, but conflicting results have been obtained. Seeds infected by F. graminearum are pink to reddish brown (Dodd \& White, 1999). They may be rotted (Sutton, 1982), and the germination reduced. A toxin, produced in seeds, reduces germination (Brodnik, 1975). In general, however, seedborne infections by Fusarium spp. rarely cause problems with seed germination of maize (Dodd \& White, 1999), because modern seed conditioning processes remove severely infected seeds from hybrid seed lots.

Munkvold \& O’Mara (2002), in order to evaluate the efficacy of three fungicidal seed treatments (captan, difenoconazole and fludioxinil) against six Fusarium species that infect maize seed or seedlings, incubated treated and nontreated seeds of two maize hybrids on the surface of an agar medium colonized by each of 12 Fusarium spp. isolates. The results showed that the fungi did not reduce seed germination, but most Fusarium spp. isolates caused decay of the seed and radicle, and arrested the development of the radicle. Aggressiveness of the isolates varied as much within a species as among species.

The objectives of this study were to identify the optimal period for incubation of maize seeds placed on agar previously colonized by $F$. graminearum; and to evaluate the effect of fungi on the germination and vigor of seeds with different infection levels.

\section{MATERIAL AND METHODS}

The seeds used in this experiment were obtained from a lot of hybrid maize D766, with $83 \%$ germination and 70 and $73 \%$ vigor, as shown by the accelerated aging and cold tests, respectively. Blotter test was used to determine fungal infection, and the results confirmed the health of the seed lot.

\section{Inoculation of maize seeds by Fusarium graminearum}

Fusarium graminearum isolate was covered with mineral oil and cultured in a tube, transferred to the surface of Petri dishes containing potato dextrose agar (PDA) culture medium. The cultures were incubated at the laboratory under $12 \mathrm{~h}$ of fluorescent light for 15 days, in which time the agar surface was completely colonized. After that period, healthy seeds, confirmed by a preliminary blotter test were placed on the surface of the agar already colonized by $F$. graminearum and incubated for 4, 8, 16 and $32 \mathrm{~h}$.

After the respective incubation periods, the seeds were removed from the culture medium and submitted to the blotter test, to determine fungal infection. Seeds were surface disinfected and soaked for $3 \mathrm{~min}$ in a $1.0 \%$ solution of sodium hypochlorite, to destroy or remove surface fungi and bacteria without killing internal organisms (Sauer \& Burroughs, 1986). Seeds with or without disinfection were placed on three layers of moist germination paper in Petri dishes. Twenty dishes containing ten seeds each, evenly spaced to avoid contact with each other, were used per treatment. The incubation was done at $20 \pm 2{ }^{\circ} \mathrm{C}$, with a $12-$ $\mathrm{h}$ day-night NUV light cycle for $24 \mathrm{~h}$, followed by a $24 \mathrm{~h}$ exposure at $-20^{\circ} \mathrm{C}$ and subsequent return to the normal incubation for five days. Following this period, the test was interpreted, and the percentage of contaminated and/or infected seeds was recorded.

Analysis of variance was conducted as an entirely randomized design, in factorial outline $4 \times 2$ (contact periods of the seeds with the fungus $\mathrm{x}$ seeds with and without surface disinfection). All treatments were replicated five times. The means were compared by Tukey test, at 5\% of probability. Percentage data were transformed in arc sine $\sqrt{\mathrm{x} / 100}$ transformation.

\section{Effect of Fusarium graminearum on germination and vigor of maize seeds}

After identifying the optimal period for incubation of seeds, where the fungus were associated with all seeds after the surface disinfection with sodium hypochlorite, seeds from the same sample were again placed on the colonized agar for infection. Following this period, healthy and infected seeds were blended, resulting in seed lots with infections of $0,20,40,60,80$ and $100 \%$.

The germination test was performed as prescribed in the Rules for Seed Analysis (Brasil, 1992). Four replications of 50 seeds each were placed on moist towels paper, which were rolled and kept at $25^{\circ} \mathrm{C}$, for seven days, when the percentage of normal seedlings was recorded.

For testing vigor, the cold test was employed in accordance with the Seed Vigor Testing Handbook (AOSA, 1983). Four replications of 50 seeds each were placed in gerboxes containing a mixture of sand and soil (2:1). Water was added to reach $70 \%$ retention capacity of the substratum. 
The boxes were covered and placed in cold camera $\left(10{ }^{\circ} \mathrm{C}\right)$ for seven days; following the cold treatment, the boxes were uncovered and maintained at laboratory temperature (25$30{ }^{\circ} \mathrm{C}$ ) for seven days, when the percentage of normal seedlings was recorded. The accelerated aging test was conducted using with four replications of 50 seeds each (AOSA, 1983; Hampton \& Tekrony, 1995). Seeds from each treatment were placed on a screen, suspended over distilled water inside gerbox, and subjected to a period of accelerated aging, in aging camera, at $45{ }^{\circ} \mathrm{C}$ near $100 \%$ relative humidity, for $72 \mathrm{~h}$. Following the aging period, the water content and germination of seeds were determined.

The experimental design was entirely randomized. The means were compared by Tukey test at 5\% probability. Percentage data were transformed in arc sine $\sqrt{\mathrm{x} / 100}$ transformation.

\section{RESULTS AND DISCUSSION}

The results of percentage of seeds contamined in the different contact periods of the seeds with the pathogen showed that $95 \%$ of the seeds presented $F$. graminearum infection after only $32 \mathrm{~h}$ of contact. Seed is considered contaminated when the pathogen is stuck to its surface, and infected when the pathogen is found inside its tissues.

Sauer \& Burroughs (1986) stated that the purpose of shaking the seeds in a $1-5 \%$ sodium hypochlorite $(\mathrm{NaOCl})$ solution is to destroy or remove surface fungi and bacteria without killing internal organisms. Destruction of spores on seed surfaces depends on the kind and condition of seeds; the amount of surface contamination; the brand, $\mathrm{pH}$, and concentration of $\mathrm{NaOCl}$; and exposure time.

Several researchers have obtained success using the same technique of placing the seeds in contact with a pathogen-colonized culture medium. Tanaka et al. (1989) inoculated cotton (Gossypium hirsutum L.) seeds with

TABLE 1 - Percentage of maize (Zea mays) seeds contaminated for Fusarium graminearum in the different contact periods of the seeds with the pathogen

\begin{tabular}{|c|c|c|c|c|}
\hline \multirow{2}{*}{$\begin{array}{l}\text { Contact period } \\
\text { (hours) }\end{array}$} & \multicolumn{4}{|c|}{$\%$ contaminated seeds } \\
\hline & \multicolumn{2}{|c|}{$\begin{array}{c}\text { Without previous } \\
\text { asepsis }\end{array}$} & \multicolumn{2}{|c|}{$\begin{array}{l}\text { With previous } \\
\text { asepsis }\end{array}$} \\
\hline 4 & $23.79 \mathrm{Ba}^{1,2}$ & $81^{3}$ & $18.79 \mathrm{Bb}$ & 52 \\
\hline 8 & $25.90 \mathrm{Aba}$ & 95 & $18.75 \mathrm{Bb}$ & 52 \\
\hline 16 & $26.63 \mathrm{Aa}$ & 100 & $20.84 \mathrm{Bb}$ & 63 \\
\hline 32 & $26.63 \mathrm{Aa}$ & 100 & $25.89 \mathrm{Aa}$ & 95 \\
\hline \multicolumn{2}{|c|}{ Test F (Contact period) } & \multicolumn{2}{|c|}{$17,7207 * *$} & \\
\hline \multicolumn{2}{|l|}{ Test F (Asepsis) } & \multicolumn{2}{|c|}{$83,3173 * *$} & \\
\hline \multicolumn{2}{|c|}{ Test F (Period x Asepsis) } & \multicolumn{2}{|c|}{$7,3044 * *$} & \\
\hline \multicolumn{2}{|l|}{ C.V. $(\%)$} & \multicolumn{2}{|c|}{6,9136} & \\
\hline
\end{tabular}

Colletotrichum gossypii (South) var. cephalosporioides A. S. Costa and related that $12-48 \mathrm{~h}$ contact periodo of seeds on inoculum resulted in infection, by penetration of fungus through seed coat, being $24 \mathrm{~h}$ the optimal period of contact. In shorter periods the pathogen could not penetrate the seed at a satisfactory level, and in longer periods the seed could absorb water to a degree sufficient to delay germination. Valarini \& Menten (1991) verified that the contact period of $36 \mathrm{~h}$ was enough to infect $100 \%$ of bean (Phaseolus vulgaris L.) seeds infected with Xanthomonas campestris pv. phaseoli (Smith) Dye. Rolim et al. (1990) used that technique to inoculate Alternaria sp. in bean seeds, and related that the inoculation of seeds, as a previous stage of Koch postulates, is a viable technique for studies of transmissiability of the pathogen.

To evaluate a laboratory method for assessing the efficacy of maize seed treatments against Fusarium spp. and the aggressiveness of Fusarium sp. isolates toward maize seeds, Munkvold \& O'Mara (2002) placed seeds treated with fungicides on the surface of the agar already colonized by Fusarium sp. isolates. The authors related that the laboratory experiments were less time-consuming and more sensitive in detecting the differential effects of the fungicide treatments. Another advantage of the inoculation of seeds per contact with the pathogen over seeds infected naturally is obtained in desired and prior-established levels (Tanaka et al., 1989).

According to the data for germination and vigor of seeds (Table 2) germination ranged from 77 to $87 \%$ among the treatments. There were no significant effects of fungal infection on germination of seed at any of the infection levels, probably due to the high vigor of the maize lot tested. These results are in agreement with those obtained by Kabeere et al. (1997), Dodd \& White (1999) and Munkvold \& O’Mara (2002), who did not find a relationship between infection

TABLE 2 - Effect of different infection levels of maize (Zea mays) seeds with Fusarium graminearum on the germination (G) and the vigor tests accelerated aging (AA) and cold (C)

\begin{tabular}{|c|c|c|c|c|c|c|}
\hline \multirow{3}{*}{$\begin{array}{c}\% \text { contaminated } \\
\text { seeds }\end{array}$} & \multirow{2}{*}{\multicolumn{2}{|c|}{ G\% }} & \multicolumn{4}{|c|}{ Vigor } \\
\hline & & & \multicolumn{2}{|c|}{$\mathbf{A A}$} & \multicolumn{2}{|l|}{$\mathrm{C}$} \\
\hline & $65.17^{1,2}$ & $82^{3}$ & $20.59 \mathrm{~B}$ & 13 & $32.55 \mathrm{~B}$ & 29 \\
\hline 80 & 68.56 & 87 & $14.20 \mathrm{~B}$ & 6 & $32.55 \mathrm{~B}$ & 29 \\
\hline 60 & 65.84 & 83 & $19.13 \mathrm{~B}$ & 11 & $31.54 \mathrm{~B}$ & 28 \\
\hline 40 & 64.04 & 81 & $18.98 \mathrm{~B}$ & 11 & $32.55 \mathrm{~B}$ & 29 \\
\hline 20 & 62.76 & 79 & $20.67 \mathrm{~B}$ & 13 & $36.50 \mathrm{AB}$ & 36 \\
\hline 0 & 61.46 & 77 & $28.54 \mathrm{~A}$ & 23 & $45.06 \mathrm{~A}$ & 50 \\
\hline Test $\mathrm{F}$ & \multicolumn{2}{|c|}{$1,66^{\mathrm{NS}}$} & \multicolumn{2}{|c|}{$7,99^{* *}$} & \multicolumn{2}{|c|}{$4,43^{* *}$} \\
\hline C.V. $(\%)$ & \multicolumn{2}{|c|}{5,99} & \multicolumn{2}{|c|}{16,18} & \multicolumn{2}{|c|}{13,97} \\
\hline
\end{tabular}

${ }^{1}$ Data transformed in arcsine $\sqrt{\mathrm{x} / 100}$;

${ }^{2}$ Values followed by the same letter, capital letter in the column and lower case in the line, do not differ to each other, for Tukey test, to $5 \%$;

${ }^{3}$ Original data in $\%$;

** Significant to $1 \%$. 
by $F$. graminearum and the germination of maize seeds.

To determine whether $F$. graminearum is seed transmitted, Kabeere et al. (1997) verified that the pathogen had no effect on germination of high infection seed samples at $25^{\circ} \mathrm{C}$. Fusarium graminearum is known to cause seed rot and seedling blight before emergence, resulting in poor seedling emergence and blighting after emergence (Dickson, 1923; Christensen \& Wilcoxson, 1966). Soil temperature is reported to be the most important factor determining the extent of seed rot and seedling blight, and above $24{ }^{\circ} \mathrm{C}$ no blighting occurs (Dickson, 1923). According to Kabeere et al. (1977) this may explain the results of their experiments.

In essence, because the germination test is conducted under favorable conditions, it basically establishes the maximum plant-producing ability of the seed. When field conditions are optimum, the germination test may correctly predict field performance of the seed lot. For the most part, however, germination values overestimate actual field emergence. Germination tests predicting $80 \%$ seldom reach this value of actual emergence under field conditions in the most instances, field emergence is considerably less (Copeland \& McDonald, 2001).

Epidemiological studies in vegetable protection have revealed that any type of pathogen association with seed assures the development of diseases by sowing, although all the pathogens present in seeds are potentially capable of starting the disease process (Tanaka \& Machado, 1985). Establishment and development of an infection within a seedling or subsequent plant is the last decisive link in the process of seed transmission, and this link can only be established if completion of the infection process has been positively demonstrated to the exclusion of other means of transmission (Neergaard, 1979). The transmission chances are higher if the pathogen lodges more internally in the seeds (Machado, 2000).

In vigor tests of accelerated aging (Table 2), all the treatments differed statistically from the control (no contaminated seeds), showing that the seeds infected by $F$. graminearum suffer the loss of their germination capacity after artificial aging. However, there was no significant difference among the treatments with $20,40,60,80$ and $100 \%$ of infected seeds, indicating that, at least at laboratory tests, a sample of seed with $20 \%$ of infection suffers the same damages in vigor that a sample with 40, 60 and 100\% of infected seeds.

The results of the cold test indicate significant differences among the treatments with 40, 60, 80 and 100\% of infected seeds and the control (Table 2). The treatment containing $20 \%$ of infected seeds did not differ significantly from control nor from the other treatments.

Seeds with low vigor have structures which are predisposed to the severe action of pathogens. Thus, the use of seeds with low vigor can have negative effects, like low germination stand. Low vigor seeds presented higher vulnerability to the attack of pathogens present during germination (Carvalho \& Nakagawa, 2000).
Based on the results obtained in this study, it can be concluded that the contact period of $32 \mathrm{~h}$ of seeds with $F$. graminearum was enough to obtain infected seeds; the fungal infection did not present effect on the germination of the seeds in any of the infected levels; and for the vigor tests, the infection levels differed significantly from the control, but not among each other.

\section{LITERATURE CITED}

AOSA. ASSOCIATION OF OFFICIAL SEED ANALYSTS. Seed vigor testing handbook. Lincoln. AOSA. 1983.

BRASIL. MINISTÉRIO DA AGRICULTURA E REFORMA AGRÁRIA. Regras para análise de sementes. Brasília. SNAD/ DNDV/CLAV. 1992.

BRODNIK, T. Influence of toxic products of Fusarium graminearum and Fusarium moniliforme on maize seed germination and embryo growth. Seed Science and Technology 3:691-696. 1975.

CARVALHO, N.M. \& NAKAGAWA, J. Sementes:ciência, tecnologia e produção. Jaboticabal. FUNEP. 2000.

COPELAND, L.O. \& McDONALD, M.B. Seed pathology and pathological testing. In: Copeland, L.O. \& McDonald, M.B. (Eds.) Principles of Seed Science and Technology. $4^{\text {th }} \mathrm{ed}$. Massachusetts. Kluwer Academic Publishers. 2001. pp.354-379.

CHRISTENSEN, J.J. \& WILCOXSON, R.D. Stalk rot of corn. Minnesota. The American Phytopathological Society. 1966.

DICKSON, J.C. Influence of soil temperature and moisture on the development of the seedling-blight of wheat and corn caused by Gibberella saubinetti. Journal of Agricultural Research 23:837870. 1923.

DODD, J.L. \& WHITE, D.G. Seed rot, seedling blight, and damping-off. In: White, D.G. (Ed.) Compendium of Corn Diseases. Saint Paul. The American Phytopathological Society. 1999. pp.1011.

HAMPTON, J.P. \& TEKRONY, D.M. Handbook of vigor test methods. Zürich. ISTA. 1995.

KABEERE, F., HAMPTON, J.G. \& HILL, M.J. Transmission of Fusarium graminearum (Schwabe) from maize seeds to seedlings. Seed Science and Technology 25:245-252. 1997.

KHONGA, E.B. \& SUTTON, J.C. Inoculum production and survival of Gibberella zea in maize and wheat residues. Canadian Journal of Plant Pathology 10:232-239. 1988.

MACHADO, J.C. Patologia de sementes: significado e atribuições. In: Carvalho, N.M. \& Nakagawa, J. (Eds.) Sementes: ciência, tecnologia e produção. Jaboticabal. FUNEP. 2000. pp.522-588.

McGEE, D.C. Maize Diseases. A Reference for Seed Technologists. Minnesota. APS Press. 1988.

MOHAMED, H.A., ASHOUR, W.E., SIRRY, A.R. \& FATHI, S.M. Fungi causing seedling blight of corn in the United Arab Republic. Plant Disease Reporter 52:84-86. 1968.

MUNKVOLD, G.P. \& O'MARA, J.K. Laboratory and growth chamber evaluation of fungicidal seed treatments for maize seedling blight caused by Fusarium species. Plant Disease 86:143150. 2002.

NEERGAARD, P. Seed Pathology. London. The Macmillan Press 
Limited. 1979.

PEARSON, N.L. Parasitism of Gibberella saubinetti on corn seedlings. Journal of Agricultural Research 43:569-596. 1931.

ROLIM, P.R.R., CENTURION, M.A.P.C. \& MENTEN, J.O.M. Alternaria em feijoeiro (Phaseolus vulgaris): incidência na semente, tipos morfológicos, patogenicidade e transmissibilidade de diferentes isolados. Summa Phytopathologica 16:130-139. 1990 .

SAUER, D.B. \& BURROUGHS, R. Desinfection of seed surfaces with sodium hypochlorite. Phytopathology 76:745-749. 1986.

SUTTON, J.C. Epidemiology of wheat head blight and maize ear rot caused by Fusarium graminearum. Canadian Journal of Plant
Pathology 4:195-209. 1982.

TANAKA, M.A.S. \& MACHADO, J.C. Patologia de sementes. Informe Agropecuário 11:40-46. 1985.

TANAKA, M.A.S., MENTEN, J.O.M. \& MARIANO, M.I.A. Inoculação artificial de sementes de algodão com Colletotrichum gossypii var. cephalosporioides e infecção das sementes em função do tempo de exposição ao patógeno. Summa Phytopathologica 15:232-237. 1989.

VALARINI, P.J. \& MENTEN, J.O.M. Inoculação artificial de sementes de feijão com Xanthomonas campestris pv. phaseoli e seu efeito sobre a qualidade sanitária e a germinação. Summa Phytopathologica 17:227-231. 1991. 